\title{
STRATEGIC RESPONSES TO CRISIS: CASE STUDY OF UNIVERSITIES IN UGANDA DURING COVID-19
}

\author{
Gregory Tweheyo $^{1}$ and Alex Mugarura ${ }^{2}$ \\ ${ }^{1}$ Bustema University, Uganda \\ ${ }^{2}$ Makerere University Business School, Uganda
}

DOI: 10.46609/IJSSER.2021.v06i04.009 URL: https://doi.org/10.46609/IJSSER.2021.v06i04.009

\begin{abstract}
The study examined the short-term impact of COVID-19 crisis on University Education in Uganda and strategies being adopted by Universities in Uganda to cope up with COVID-19 shocks. The study used a cross-sectional research design and the online questionnaire to collect data from 21 universities and other degree awarding institutions.

From the study, it was shown that lack of continuity in teaching and learning was at the heart of the crisis as most universities in Uganda are campus based and this was attributed to inadequate infrastructure and equipment to rollout ODeL. In addition, all universities experienced a sharp decline in students' admissions, revenue collections thus lack of capacity to pay salaries to staff members, especially private universities. However, amidst the broad challenges COVID-19 posed, the crisis created opportunities of promotion of remote-working; development and implementation of online and blended programs, attitude change towards e-learning training, increased innovation and improved technological competency of staff and also university collaboration and partnerships. The following strategies were being employed to mitigate the crisis; universities have delayed the start dates until the reopening of universities by the line authorities, changed the application deadlines for the next intake programs and others are switching to online teaching. High internet connectivity, poor internet connectivity in rural areas, lack of required access equipment by students and lack of technological infrastructure are some of the challenges universities are facing to scale up ODeL. There is need to address infrastructure issues and lack of access equipment, universities should consider sharing of educational materials and resources among themselves and other institutions, national digital policy learning framework. The universities should develop virtual laboratories to support the online teaching of practical and practicum/lectures, review the programs and ensure that they are accredited by NCHE as online programs as it requirement by law and training both students and staff on the use of digital delivery models before the implementation by the institutions among others all inevitable.
\end{abstract}




\section{International Journal of Social Science and Economic Research}

ISSN: $2455-8834$

Volume:06, Issue:04 "April 2021"

Keywords: Covid-19, Coronavirus, Strategic Responses, Universities and crisis management.

\section{Introduction}

In March 2020, novel coronavirus (COVID-19) was declared a global pandemic by the World Health Organization. The pandemic has triggered worldwide panic as the numbers of victims explode currently (September 15, 2020) standing at 922,252 deaths, with more than 28,918,900 people infected (World Health Organization dashboard, 2020). The COVID-19 projected consequences were further echoed by the Japanese Finance Minister Taro Aso at G20 in Riyadh, Saudi Arabia, on February 24, 2020 who said, "The spread of the new coronavirus is a public health crisis that could pose a serious risk to the macro economy through the halt in production activities, interruptions of people's movement and cut-off of supply chains". Kristalina Georgieva, Managing Director of the International Monetary Fund (IMF) at a briefing for the World Health Organization (WHO) on Friday, 3 April, 2020 said, "This is a crisis like no other," he noted that the crisis was like nothing the agency had seen in 75 years and one that would be more severe than the last global financial crisis.

The COVID-19 pandemic has exposed the daunting deficiencies of education systems in many countries. This is happening at a time when the world is living with a learning crisis with over 258 million children and youth of primary- and secondary-school age out of school (World Bank Group, 2020).This pandemic threatens education progress worldwide through two major shocks: the near-universal closing of schools at all levels and the economic recession sparked by pandemic-control measures. The twin shocks of school closures and global recession could have long-term costs to education and development, if governments do not move quickly to counter them (World Bank Group, 2020).

In Uganda, His Excellency the President of the Republic of Uganda ordered the closure of institutions of learning for 30 days, with effect from Friday 20th March 2020 to mitigate the spread of the virus. All education and training institutions/schools in Uganda are still under lockdown (NCHE , 2020). The closure of institutions, including Universities and Other Tertiary Institutions, disrupted education in the country. As a result, the Ministry of Education and Sports designed the Preparedness and Response Plan to COVID-19, with a focus on continuity of learning, among others. On the 4th April 2020, the Minister of Education and Sports addressed the nation on the Education Sector preparedness and response to the COVID-19. The minister echoed that: (a) The Governing Councils of Universities and other Tertiary Institutions were directed to put measures in place that would ensure continuity of remedial (revision) learning for all learners and (b) The continuation of systematic curriculum coverage would take place at institutions after reopening (NCHE , 2020). The government does not have a clear roadmap 


\section{International Journal of Social Science and Economic Research}

ISSN: $2455-8834$

Volume:06, Issue:04 "April 2021"

when education institution will resume. This has created a lacuna on which strategic intervention can be developed and rolled out by Universities.

In response, the NCHE provided guidance to Higher Education Institutions (HEIs) for both medium and long terms. The NCHE proposed Open Distance E-Learning (ODeL) as relief and went ahead to provide the minimum standards to guide the development of all programmes leading to Higher Education awards. The scope of the minimum standards of ODeL guided by NCHE includes open, distance and e-learning offered by Higher Education Institutions through various modes. The modes include the following: (a) traditional distance education; (b) elearning provision; (c) blended learning; and (d) virtual education. In all these, the centre focus is the student and ensuring that quality in all aspects is not compromised. In addition, ODeL requires maximum interaction between the learners and the teachers, even where physical engagement is not possible (NCHE, 2020).

The University education sub sector is composed of 50 universities of which 39 private and 11 public with the current enrollment of 258,866 students (MoES, 2020). The universities are based on traditional learning (T-Learning) model of education with few offering blended learning and one offering purely virtual learning (Nexus International University former Virtual University of Uganda). The outbreak of COVID-19 that led to closure of institutions, including Universities and Other Tertiary Institutions, thrown into very uncertain waters as most of them had never thought of business continuity plan in case of any shock. Andreas Schleicher the head of education at the OECD said that "It's a great moment for learning, all the red tape that keeps things away is gone and people are looking for solutions that in the past they did not want to see" (OECD, 2020). The Covid-19 pandemic offers Universities a once-in-a-generation opportunity to put their dysfunctional strategies behind them (OECD, 2020).

The Ministry of Education and Sports Preparedness and Response Plan to COVID-19 are based mainly on adtech solutions. The success of Preparedness and Response Plan have been hindered by the digital divide across the country and has caused enormous inequality gap in implementing adtech solutions. The National IT survey 2017/2018 found that $65.3 \%$ of Ugandan households owned a radio, $21.8 \%$ owned a Television set, $5.9 \%$ had access to a computer at home, $10.8 \%$ of households owned a household telephone, $70.9 \%$ of all individuals owned a mobile phone, and $10.8 \%$ of all households had at least one member who had Internet access (NITAU, 2018). The country still has challenges of slow internet speeds and penetration as well and data costs which hold back online learning intervention being implemented by Universities. In addition, students at the institutions of higher learning did not have the appropriate equipment and means, including laptops, smartphones and reliable data access for e-learning. In response, some universities are transforming to offer remote learning opportunities to their students to ensure continuity of which it is being criticized for benefiting a small percentage of learners because of 


\section{International Journal of Social Science and Economic Research}

ISSN: $2455-8834$

Volume:06, Issue:04 "April 2021"

technology divide, thus widening the inequality gap (BMAU, 2020). The NCHE requires that programmes offered must be subjected to accreditation requirements in terms of the learner management system, assessment method, staffing and quality monitoring which has also affected flexibility of universities to quickly transform to ODeL (NCHE , 2020). The inadequacy of teachers to transform their material to suit online delivery modes is still a valid bottleneck. Little information is available about the strategic resposes being adopted by the Universities in Uganda to ensure continuity of teaching and learning. Therefore, the purpose of this paper is to examine the short-term impact of Covid-19 and explore the strategic responses being adopted by Universities in Uganda to ensure business continuity amidst the COVID-19 shock.

\section{Literature Review}

\subsection{Impact of COVID-19 crisis on University Education}

The COVID-19 pandemic has already had profound impacts on education by closing schools almost everywhere on the planet, in the largest simultaneous shock to all education systems in our lifetimes. The damage will become even more severe as the health emergency translates into a deep global recession. The school closings shock will lead to learning loss, increased dropouts, and higher inequality; the economic shock will exacerbate the damage, by depressing education demand and supply as it harms households; and together, they will exact long-run costs on human capital accumulation, development prospects and welfare (World Bank Group, 2020). This is coming at a point where 30 percent of all students in Ugandan universities either never finish their courses on time, or just drop out (New Vision, 2019). The closer of universities may result to negative psychosocial effects on learners. The learners are at home without clear roadmap on when to resume school. This could yield bad tendancies and losss of morale to education etc especialy those living in vulnarable settlements and poor backgrounds.

Universities are struggling to navigate this crisis while maintaining consistent course delivery, ensuring strong student recruitment numbers, and providing clear communication to staff and students (QS, 2020). QS,200, interviewed 400 Educational professionals in universities across the globe and the major anticipated challenges from the survey included; low student recruitment target mainly international students, revenue reduction, how to move from traditional education to e-learning and how to overcome the problem of practical courses and training. In addition, universities a facing challenges of industrial internship or attachments for most of engineering and other science students under the guise of social distancing.

The anticipated reduction in revenue arising from low student enrollments will lead to possible reduction in staffing especially Non-teaching staff and temporary contracts of Teaching-staff may be terminated with up scaling of virtual modality (UNESCO, 2020). Those Universities that 


\section{International Journal of Social Science and Economic Research}

ISSN: $2455-8834$

Volume:06, Issue:04 "April 2021"

adopt radical and fast paced approaches will have a competitive edge of being University of choice by students seeking for value for money.

The private universities in Uganda under the umbrella body, the Vice-Chancellor's Forum have appealed for bail out from Government to enable them stay afloat. The private universities requested for tax exemptions; personal protection equipment for staff; government to pay their staff for one semester; student access zero-rated internet bandwidth and revision of student loan scheme and government scholarships policy (Newvision, 2020).

\subsection{Strategic Responses to COVID-19 Crisis by Universities}

As economist Milton Friedman put it "Only a crisis - actual or perceived - produces real change. When that crisis occurs, the actions that are taken depend on the ideas that are lying around. That, I believe, is our basic function: to develop alternatives to existing policies, to keep them alive and available until the politically impossible becomes the politically inevitable." (Friedman, 2002). Therefore, crisis enables the impetus for change. Crisis management is about responding to events that are affecting your institution during the crisis, whereas risk management preparation of scenarios that may arise when the crisis is more evolved. This means not just predicting possible issues that may arise in the coming weeks, but instead looking ahead to months and years down the line and forming interdisciplinary teams to guide on every stage (QS, 2020).

OECD pointed out thirteen priority responses to COVID-19 and they are mainly focusing on flexibility in adaption since the education landscape has changed. The need to re-prioritize curriculum goals given the reality that the mechanisms of delivery are disruptive; defining what should be learned during the period of social distancing; stitching to online education strategy; develop alternative means of delivery which include but not limited to TV programs, radios; exploring partnerships with community organizations and the private sector to deliver those regulatory frameworks; need to allow educational institutions the necessary flexibility to develop adaptive responses to the crisis for example, in those jurisdictions where online instruction is not recognized by government authorities as an alternative to face to face instruction, those barriers should be removed (OECD, 2020).

In Uganda, Universities are trasforming to ODeL but most of the programmes offered online are not accredited by NCHE as legal obligation. In addition, the NCHE provided guidelines for adoption of an emergency Open, Distance and E-learning (ODeL) system by the higher education institutions during the COVID-19 lockdown in June, 2020. The guidelines requires NCHE to carry out the necessary quality assurance checks, including visitations where possible, or institutions to demonstrate the technology capability to provide teaching and learning 


\section{International Journal of Social Science and Economic Research}

ISSN: $2455-8834$

Volume:06, Issue:04 "April 2021"

remotely before granting a twelve (12) months permission offer emergency ODeL (NCHE, 2020). This move will cause delays for Universities to roll out the ODeL programs.

There is need for countries to move quickly to support continued learning to partially mitigate the damage with the right planning and policies. Countries can use this crisis as an opportunity to build more inclusive, efficient, and resilient education systems (World Bank Group, 2020). The policy responses to achieve continuity can be summarized in three overlapping phases: a) Coping, Managing Continuity, and Improving and Accelerating through remote learning that will ensure different platforms that allow them to reach as many students b) Managing Continuity, educational systems that prevent dangerous (and possibly irreversible) reductions in enrollments and to close learning gaps that will likely have expanded during the closures and c) Utilise an opportunity provided by the crisis response and innovations to build educational systems stronger and more equitable than before, in the phase of Improving and Accelerating (World Bank Group, 2020).

A rapid assessment of the experiences of COVID-19 disruption to tertiary education globally exposed many significant short- and long-term challenges facing tertiary education systems and institutions, including: diminished resources for institutions, personal and academic challenges for institutions and students, demand for improved infrastructure to support continued distance and blended learning models, reduced mobility placing pressures to improve regional and local tertiary institutions, and much more (World Bank Group, 2020).

According to the survey of 400 educational professionals in universities carried out by QS, 200, indicated that 50 percent of the Universities had switched some of their scheduled courses to online. The shift to online was supported by Robert Hsiung, China CEO of the online educational company EMERITUS who said that "The massive move to online is forcing the education system to figure out how to drive engagement at scale in their courses. This has created a special window for us to leverage our experience in supporting these schools. I believe that the coronavirus will force educators to revolutionize the way they teach, moving from a lecture-listen model toan interactive, learn-by-doing model. We are well suited to capture the wave” (QS, 2020).

The swift for tertiary education institutions towards online provision to ensure continuity of teaching and learning and, at least to some extent, exams does not only depend on the level digitalization. Countries that had not developed a strategic approach toward digitalization cannot provide the online. The offering of online goes beyond the digitalization in the narrower sense and also applies to issues like student financing, quality assurance, and the status of academic staff (Worldbank, 2020). 


\section{International Journal of Social Science and Economic Research}

ISSN: $2455-8834$

Volume:06, Issue:04 "April 2021"

The World Bank summarized ten recommendations to policy makers and tertiary education institutions, and to donors and multilateral agencies, on how to address the crisis. These include; support to the extent possible the return of staff and students to their home countries; address ICT infrastructure issues; share educational materials and resources among institutions; take timely decisions on the academic calendar (exams, admission, graduation) based on epidemiological guidance and available information; make equity a priority during the crisis and beyond, institutions should consider a freeze on staffing arrangements as long as it is feasible (staff lost by institutions and academia in some cases might be difficult to bring back); communicate with current and prospective international staff and students, take care of their specific needs and provide flexibility decision making; work with quality assurance agencies to adjust quality assurance mechanisms to the crisis and the evolving situation; ring-fence public funding for tertiary education (decreasing funding for teaching and learning, research, and innovation will harm post crisis economies in a lasting way) and plan for a gradual reopening, prioritizing the areas that would need to be accessed at the earliest opportunity (Worldbank, 2020).

The remote learning is being adopted in Uganda to ensure continuity of learning but the effectiveness of the lessons through media cannot be ensured (BMAU, 2020). BMAU, found out that remote learning will widened the inequality gap given the digital divide between urban and rural areas, and the expected parental support to learners may be limited for illiterate parents. However, the sector could improve on the innovative solutions (e-learning) being undertaken for inclusiveness by making the necessary investments in e-technology (BMAU, 2020). The issue digital divide is a global challenge, around 40 percent of the population still do not use (or do not have access to) the internet in Europe and Central Asia countries (Worldbank, 2020). The global digital challenges included; a) Weakness of internet connection and internet speed in many countries, b) High prices for a good internet connection, c) Absence of computers/laptops/tablets/smartphones that support online teaching and learning (Worldbank, 2020).

\section{Methodology}

The study used a cross-sectional research design that consisted mainly qualitative research method of data collection. This is a type of observational study design, in which the investigator measures the outcome and the exposures in the study participants at the same time. Unstructured and semi-structured qualitative method was used because of its ability to generate more in-depth information on few cases. The online questionnaires were responded to by 28 university staff from 21 universities and other degree awarding institutions (10 public and 11 private) as per annex 1, out of 50 universities of which 11 are public and 39 private. The target population included both teaching and non-teaching staff members with a major focus of heads of quality 
assurance and $\mathrm{ODeL}$ coordinators and university management members. To get a wider view on the strategic response to Covid-19 crisis, supporting data was collected from key informants from Ministry of Education and sports and other development partners engaged in education using interview guides. The data collected was coded, cleaned, and transformed to ensure completeness of the questionnaires. This was qualitatively analyzed, summarized and presented in form of tables through percentages, graphs and charts.

\section{Results}

\subsection{Short-term impact of COVID-19 crisis on University Education in Uganda.}

The researcher grouped the Short-term impact of COVID-19 crisis on University Education in Uganda into two categories; Positive and Negative impacts.

\section{a) Positive short-term impacts}

The respondents were asked about positive changes their universities experienced as result of COVID-19 lockdown which resulted into closer of universities. 92 percent of the respondents indicated that COVID-19 lockdown brought positive changes in the university education as per the Graph 1 below.

\section{Graph 1: Positive Changes Universities Experienced as result of COVID-19 Lockdown}

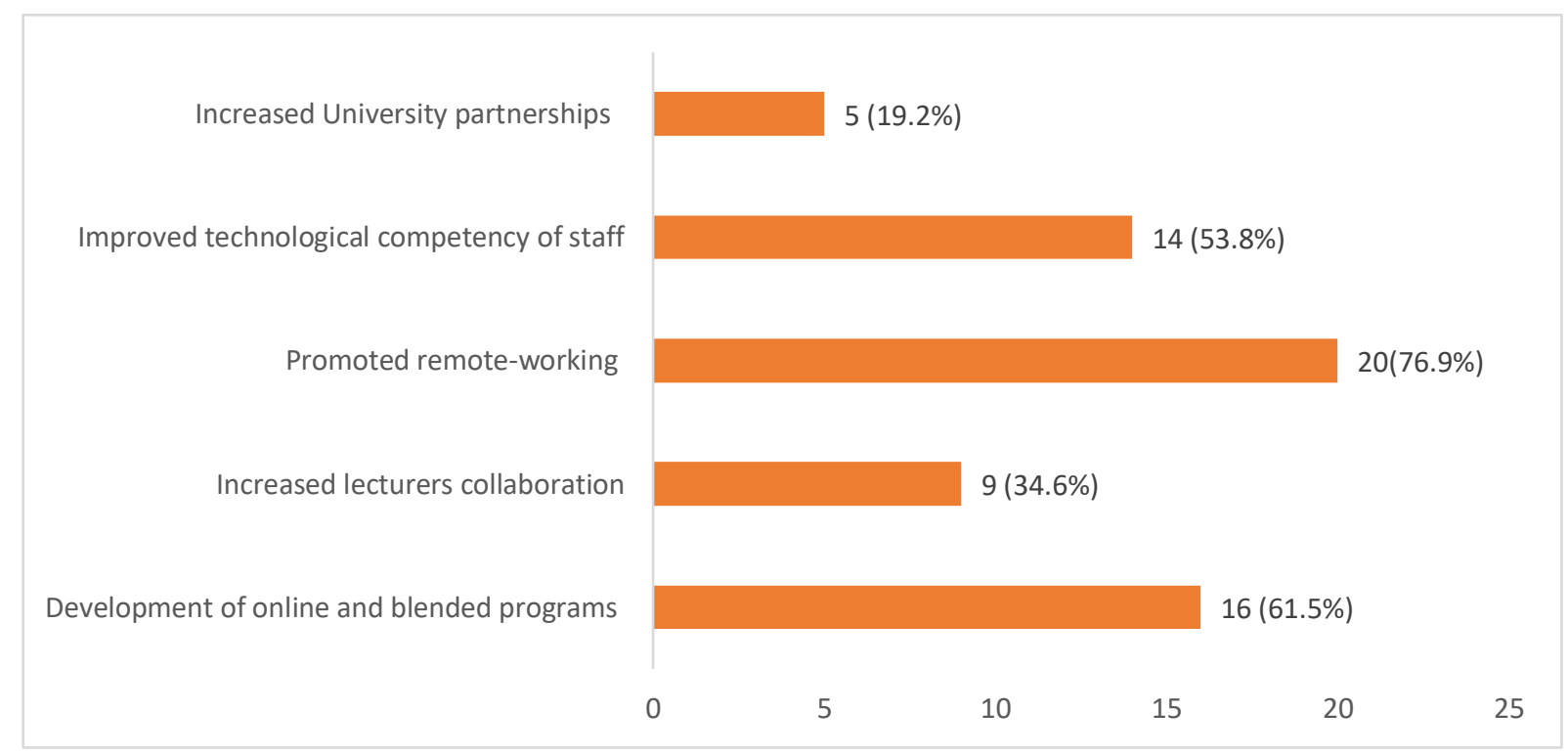

From the Graph1 above, the major positive change were; Promotion of remote-working including online meetings, the development and implementation of online and blended programs, 
improved technological competency of staff, increased lectures' collaboration and increased university partnerships respectively. Other positive changes included; attitude change towards elearning training and increases innovation such as production of sanitizer and capacity for testing for COVID-19.As one higher-education expert wrote: The switch to online learning during COVID-19 pandemic lockdown has sensitized the public to reorganize online certifications and awards which they have been biased about.

\section{b) Negative short-term impacts}

i. Lack of continuity in teaching and learning since most of the Universities are campus based. From the semi structured question, universities indicated that they continued offering teaching materials but the access is being limited by lack of infrastructure by students and staff. In addition, the uncertainty on when the universities will open affected the emergency planning in universities in a resource constrained environment. In addition, there challenges arising from teaching practical lessons online since most of the Universities had not developed the virtual laboratories. Community outreach and internships are core mandate of the University and with social distancing and slow down of economic activities, universities are find it hard to carry out those core activities. One of the respondent said " the biggest challenge is to complete internship of final student during COVID-19 lock down as it mandatory for completion"

\section{ii. Low student Enrollments}

Figure 1: Strategies used by Universities to Addressing the student Recruitment

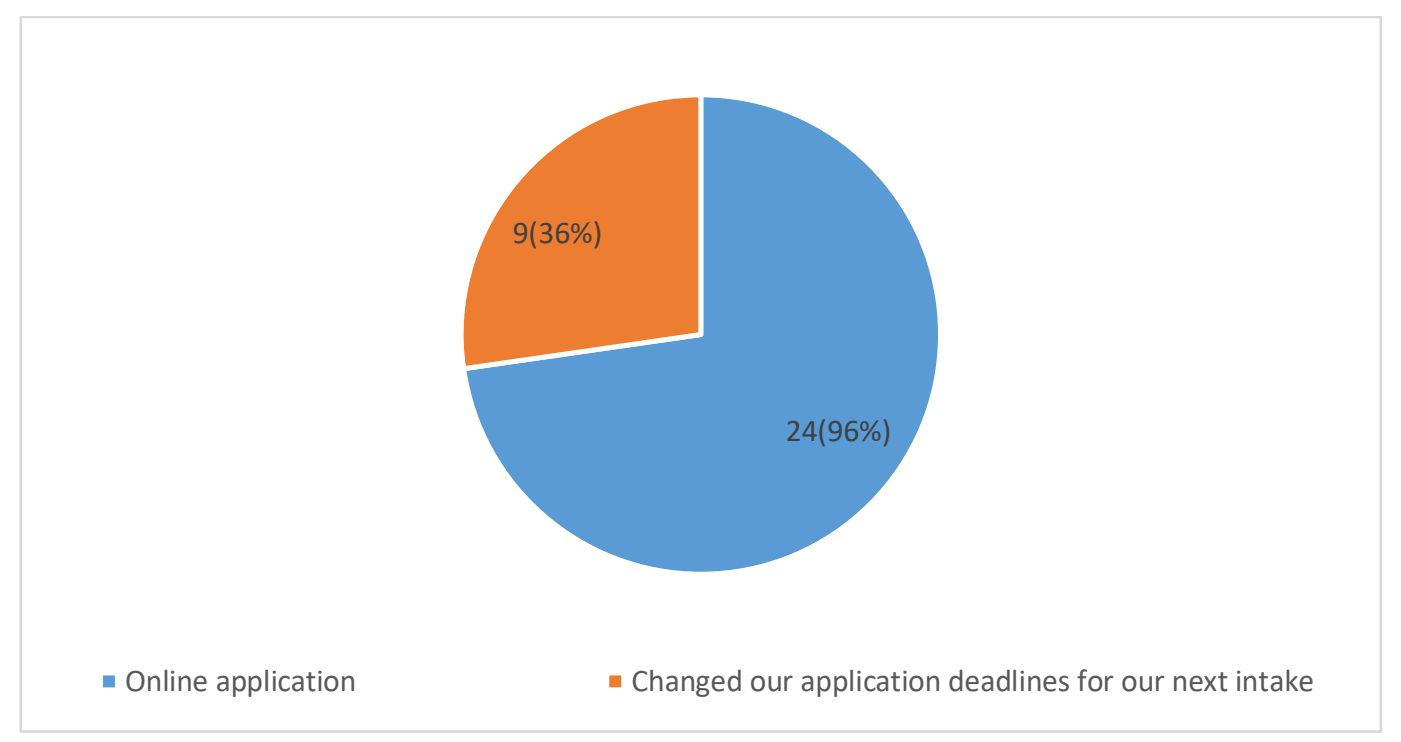


The COVID-19 lockdown came at time when universities were soliciting applications for private entry scheme. This affected the level of private admissions to universities. One of the respondents said "we will not even admit 60\% for academic year 2020/21 compared to what we admitted in academic year 2019/20". The low student admission are being achieved even when 96 percent of the universities included in the study had adopted the online application and 36 percent had extended their application deadlines for the next intake as in Figure 1 above.

\section{iii. Lack of effective crisis management plans}

Graph 2: Effectiveness of Universities Crisis Management Plan during COVID-19

\section{Lockdown}

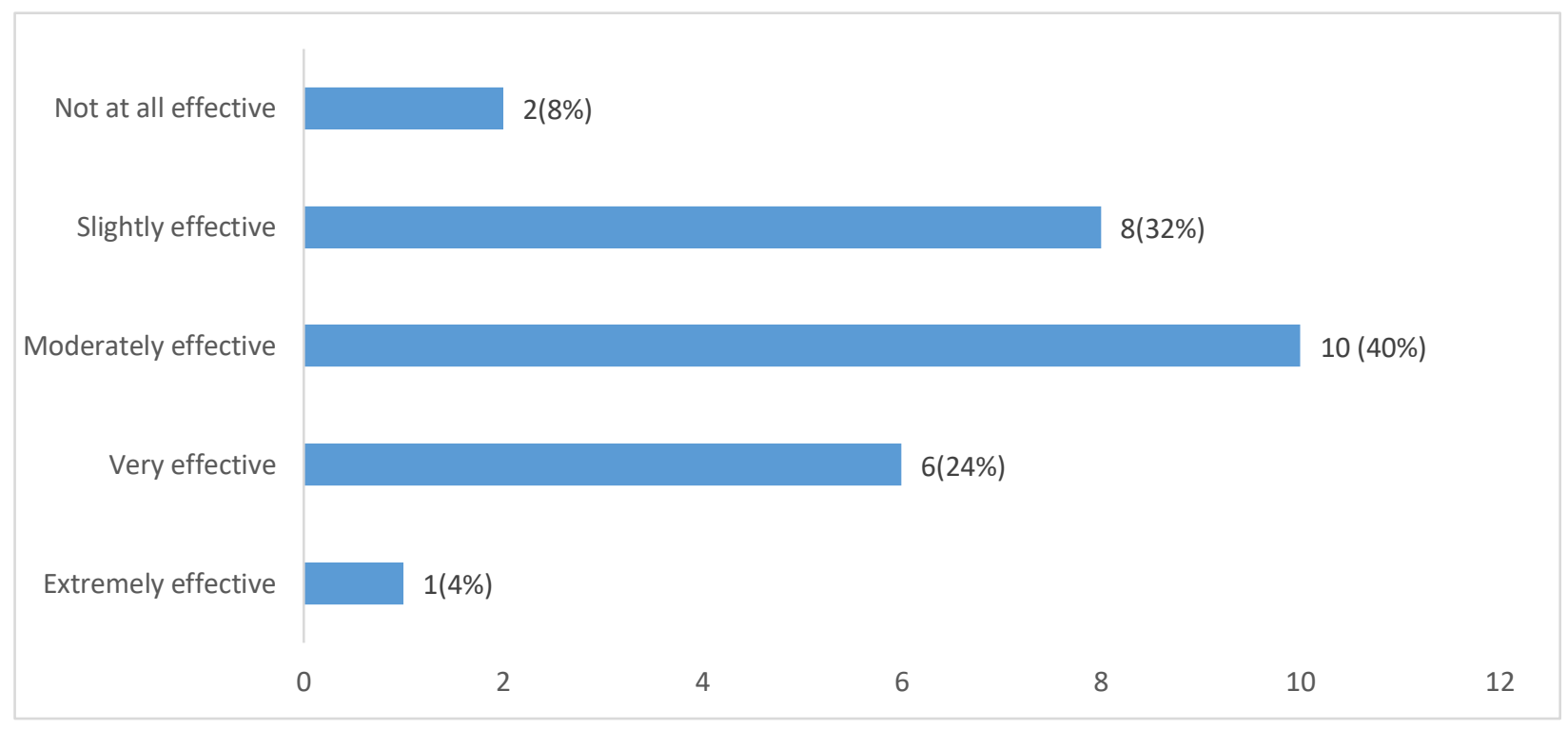

72 percent of the universities sampled had a university risk management strategy. The risk management strategies were not very effective to handle the COVID-19 shocks. Only seven respondents indicated that their risk management strategies were very effective and extremely effective as per the Graph 2 above. One of the key informant said "There seems to be a huge gap between university management plans for continuity and the student engagement. Few of the students can meet the expectations of e-learning without support in terms of digital software and hardware access, and affordability"

iv. Decline in revenue collections: 100 percent of the respondents indicated that there was sharp decline in funding both government and private universities as per Graph 3 below. 
International Journal of Social Science and Economic Research

ISSN: 2455-8834

Volume:06, Issue:04 "April 2021"

\section{Graph 3: University Revenue sources majorly affected by COVID-19}

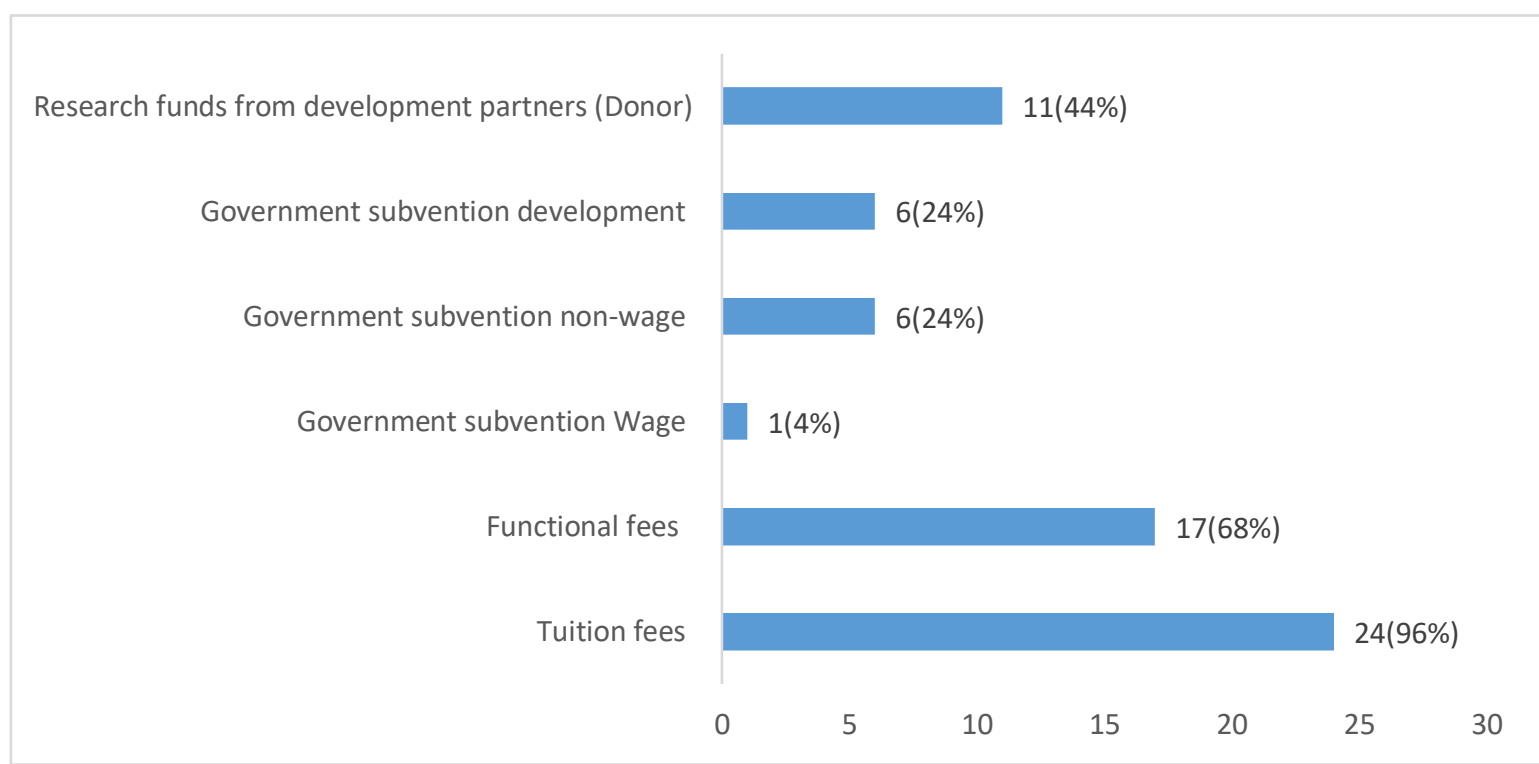

From Graph 3 above, the major sources affected were tuition fees, functional fees and research funds from Development Partners. The tuition and functional fees were mainly affected because students tend to pay towards the end of the semester as they clear for examinations and at the time of closer of the Universities, the semester was in the middle and most of the students had not yet paid. Government subvention wage was the least affected since government paid all the workers during COVID-19. The closer of universities also affected other indirect revenues from hire of premises, rentals and services.

\section{Lack of capacity to pay salaries for staff}

The sharp decline in revenue sources affected the universities capacity to pay staff salaries. Graph 4 shows the ability of universities to pay salaries for their staff. One of the respondent wrote "The private universities are lobbying government to provide special support to cater for critical need such as salaries of staff". 
International Journal of Social Science and Economic Research

ISSN: 2455-8834

Volume:06, Issue:04 "April 2021"

Graph 4: Capacity of Universities to pay salaries for Staff during COVID-19

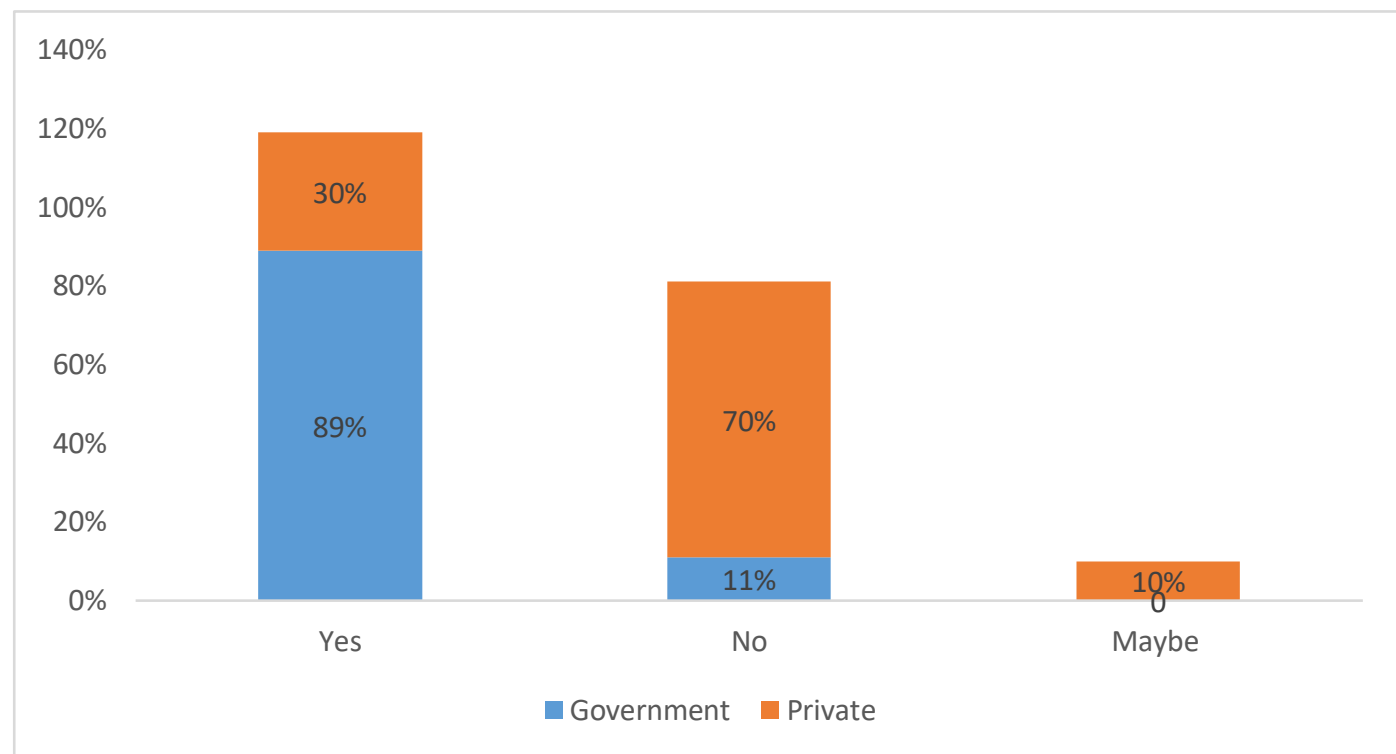

As in the graph 4 above, government universities (89\%) were able to pay salaries of staff while private Universities only $30 \%$ was able to pay salaries. In addition, the private universities are paying a percentage (ranging 50\%-30\%) not whole salary as per contract. The $11 \%$ of the staff not paid by government universities are mainly part-time staff who earn based on per time worked.

Graph 5: Categories of staff not paid by Universities during COVID-19

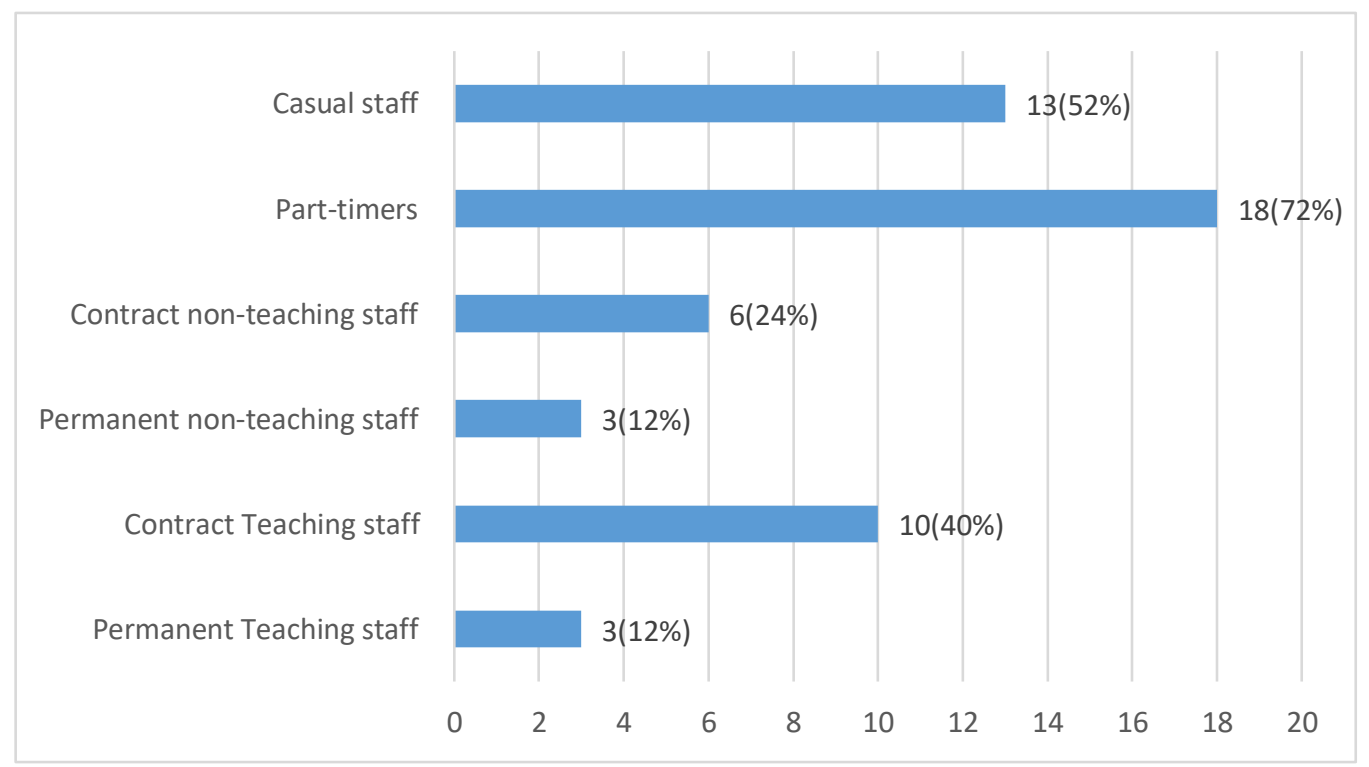


The categories of staff who were not paid were mainly par-timer (72\%) followed by casual staff (52\%) and contract non-teaching (40\%) respectively as in the graph 5 above.

\subsection{Exploring the strategies being adopted by Universities in Uganda to cope up with COVID-19 shocks}

\section{Graph 6: Tactics universities adopted for business continuity in the wake of the COVID 19 Lockdown}

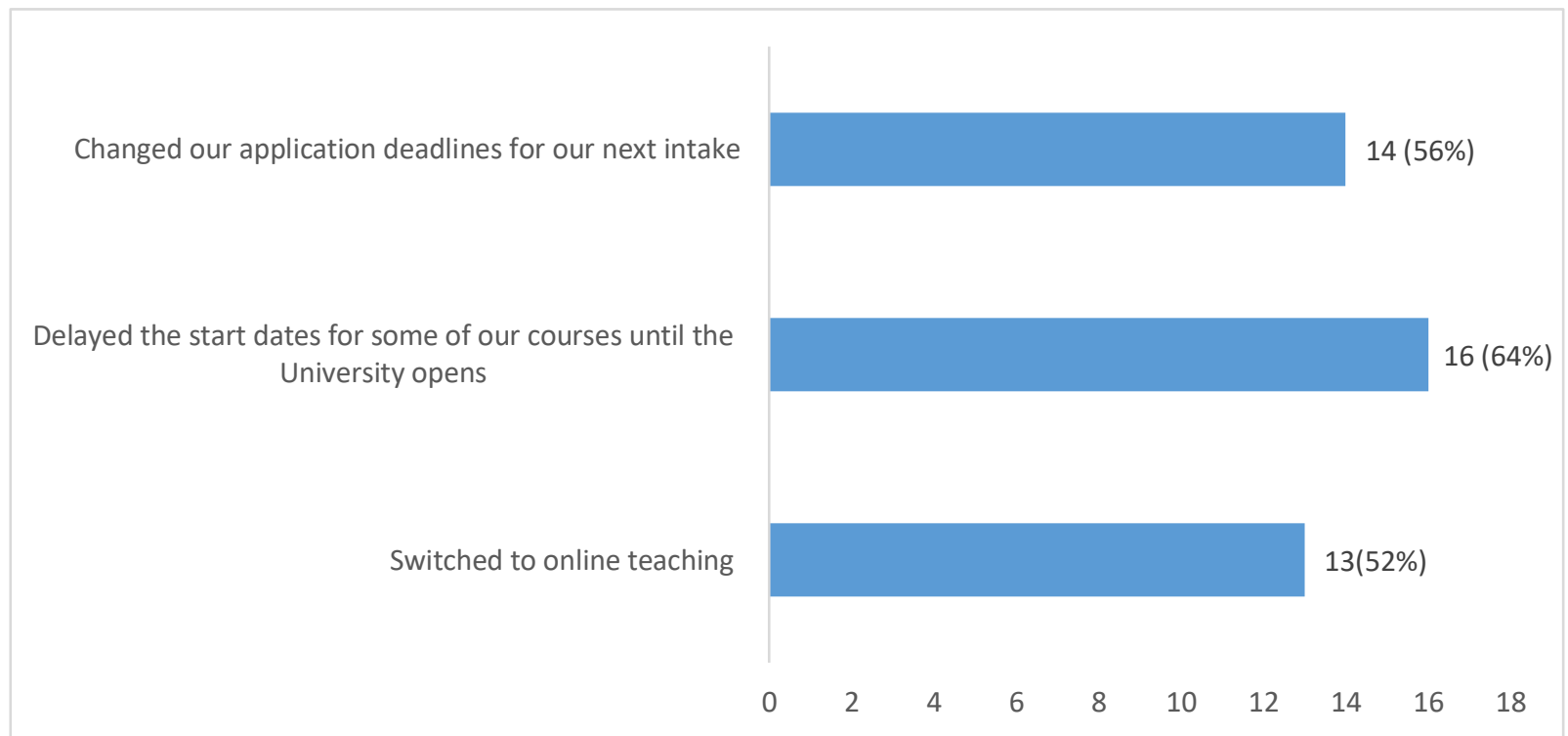

The study asked a question about the tactics universities adopted for business continuity in the wake of the COVID-19 lockdown. Results indicates that that the most common tactic used by the universities was to delay the start dates of the programs until the universities open (64\%) followed by changing of application deadlines for the next intake (56\%) and some universities switched to online teaching and governance (52\%) as indicated in the Graph 6 above. 
International Journal of Social Science and Economic Research

ISSN: $2455-8834$

Volume:06, Issue:04 "April 2021"

\section{Graph 7: Instructional Resources being used by Universities to support the academic experience of students during COVID-19 Lockdown}

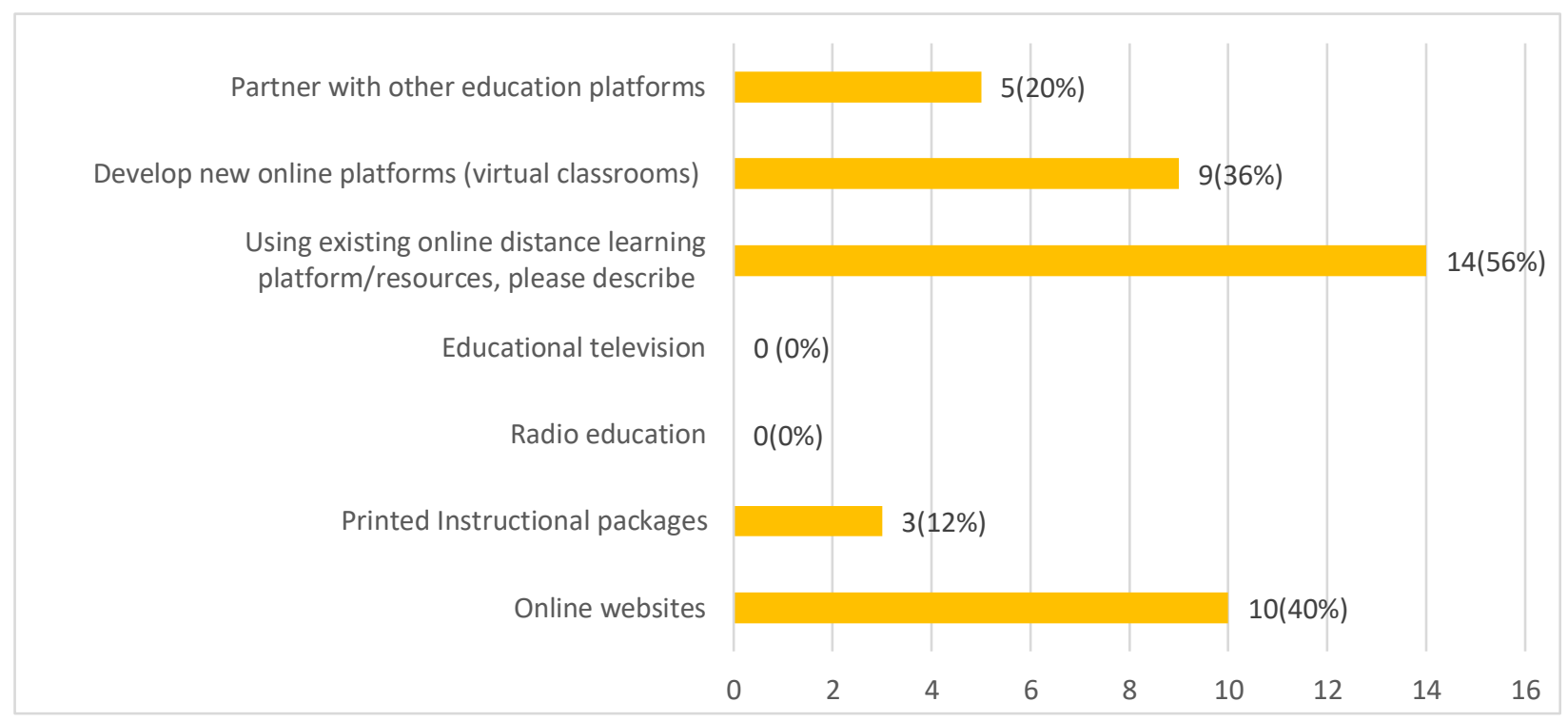

From graph 7 above, the universities were able to support the continuous learning as per government directive through mainly; using existing online distance learning platforms and resources, developing new online platform (virtual classrooms), posting materials on online and website, and partnering with other education platforms such as zoom. No single university used radio and television. The universities are mainly using Moodle, Google classroom ventures, Kolibri, CANVAS, ZOOM, webinars, Microsoft Teams, e-learning materials donoted by Wolters-Kluwe, whatsapp and facebook. One of the respodent wrote "there is need to adopt virtual laboratories to support practical and practicum programs. The Universities need to reimagine and shift pedagogy inline to match the fourth industrial revolution skills requirements".

In addition, the universities are planning to develop new online platforms (virtual classrooms) so that lecturers can continue engaging with students or collaborative learning; blended learning model (short attendance periods on campus for practical's accompanied by a high degree of Elearning) and use of online website as major interventions in case of delayed re-opening of universities as per the Graph 8 below: 
International Journal of Social Science and Economic Research

ISSN: 2455-8834

Volume:06, Issue:04 "April 2021"

Graph 8: Teaching modes Universities are planning to Adopt in case of delayed Re-opening

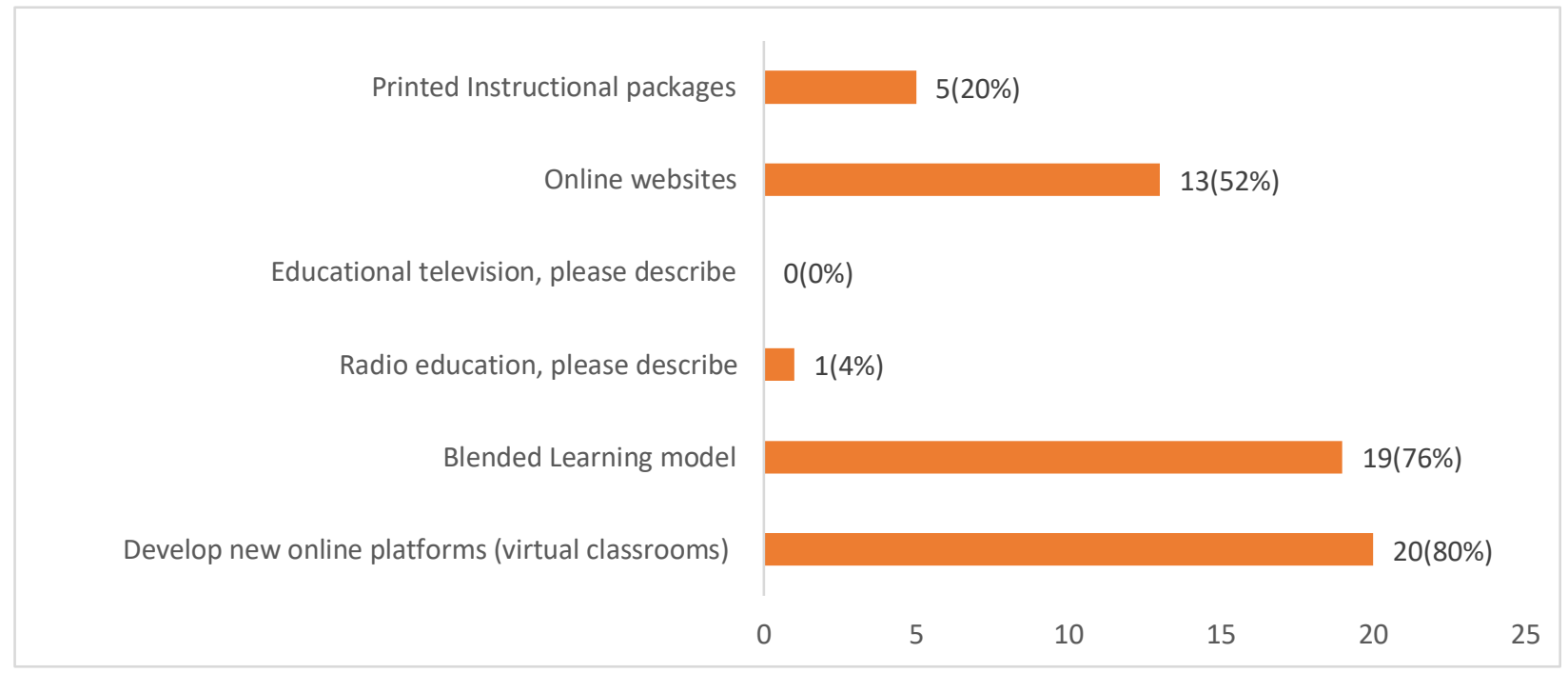

\subsection{Challenges Faced by Universities to Scale up ODeL}

\section{Graph 9: Challenges Faced by Universities to Scale up ODeL}

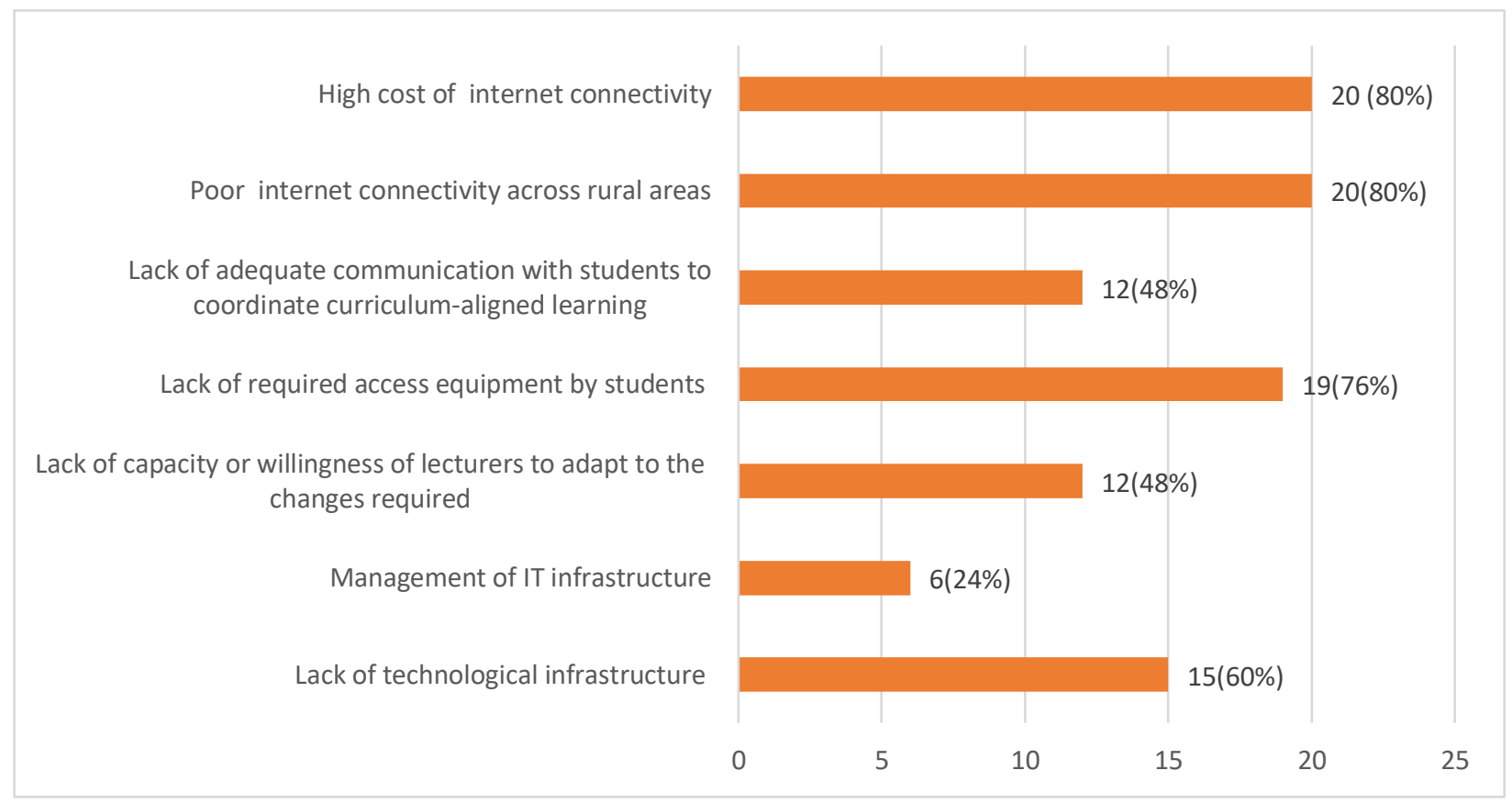

The Universities mainly adopted ODeL strategies for business continuity. They still face challenges of poor internet connectivity across rural areas (80\%); high cost of internet connectivity (80\%); lack of required access equipment by students such as laptops, smart phones, 


\section{International Journal of Social Science and Economic Research}

ISSN: $2455-8834$

Volume:06, Issue:04 "April 2021"

ipads etc (76\%); lack of technological infrastructure at universities $(60 \%)$; lack of capacity or willingness of lecturers to adapt to the changes required (48\%); lack of adequate communication with students to coordinate curriculum-aligned learning (48\%) and lack of management capacity of IT infrastructure at universities (24\%). In addition, the key informants highlighted the lack of organized course materials for online learning, negative attitude about e-learning and lack of national e-learning policy as major hindrance for continuity learning.

However, the universities suggested as in graph 10, that ODeL can be scaled up through; provision of internet connectivity across rural areas (92\%); reduction of the cost of internet across the country (92\%); training of lecturers to adapt to the changes required $(84 \%)$; provision of the technological infrastructure to universities (76\%); training of students to adapt to the changes required and give time to students to acquire the required access equipment respectively.

\section{Graph 10: Requirements by Universities to Scale up ODeL}

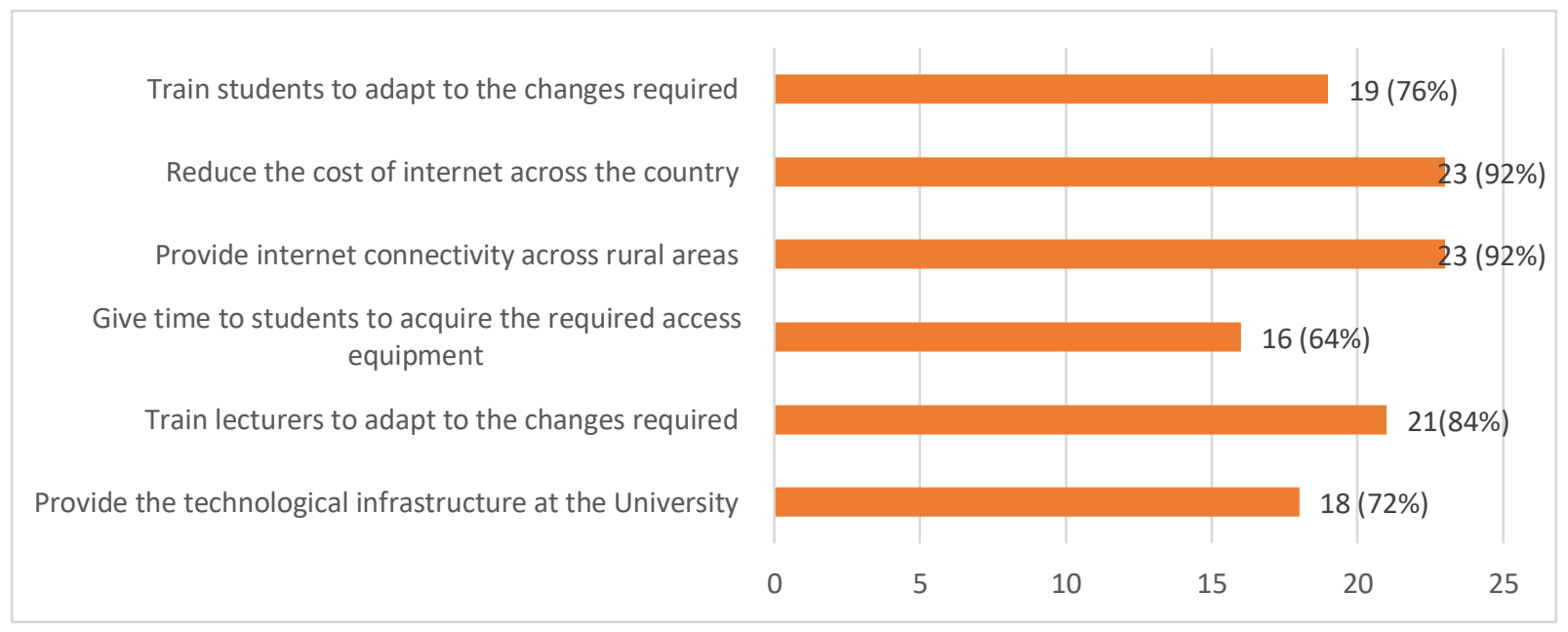

From Graph 11 above, 69.2\% percent of the respondents indicated that the mode of delivery being used does not benefit all the students and only 26.9 percent of the students were trained before the roll out. This will cause a big disparity in learning across the students. In addition, 69.2 percent of the respondents indicated that staff were trained on the mode of delivery before it was rolled. 54 percent of the respondents said that their universities are willing to share teaching materials but there is need for policy framework. 
International Journal of Social Science and Economic Research

ISSN: 2455-8834

Volume:06, Issue:04 "April 2021"

\section{Graph 11: Preparedness of Universities to Rollout ODeL}

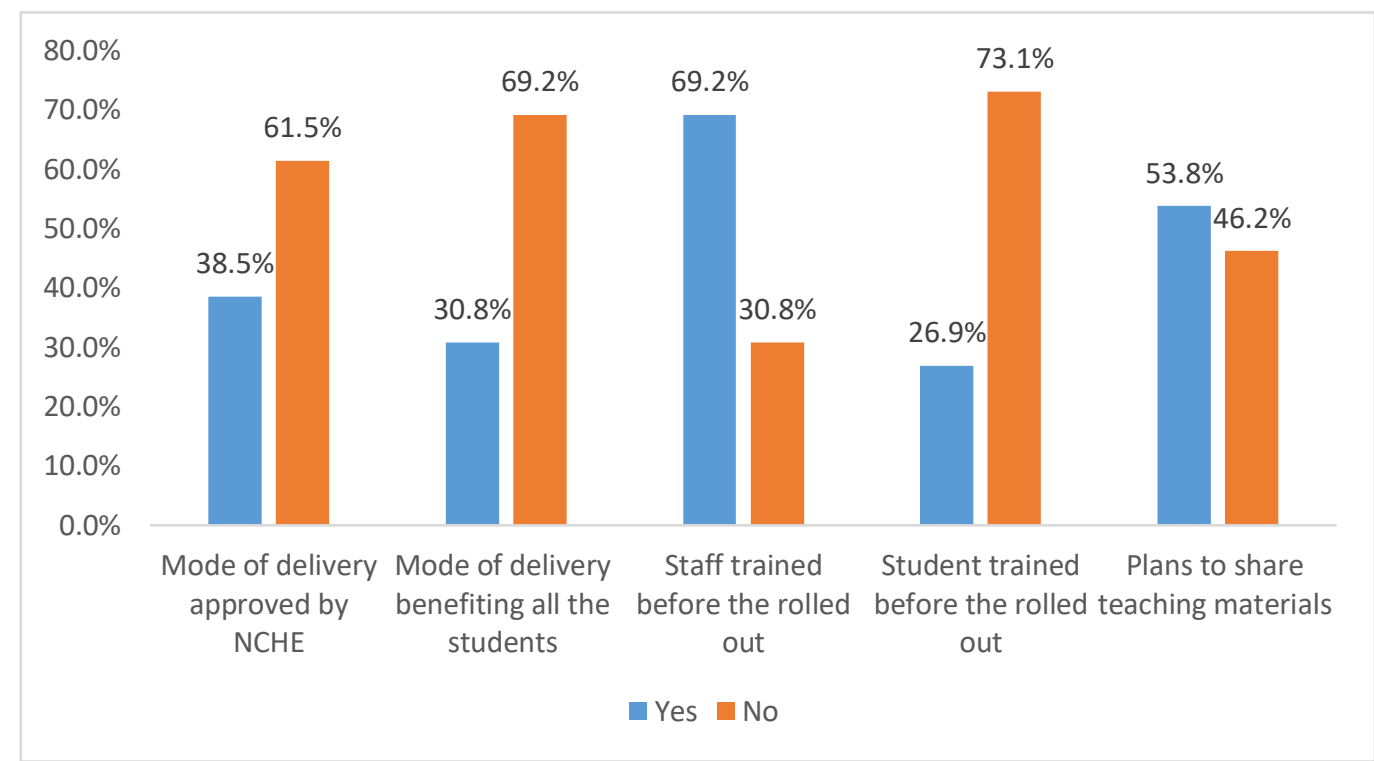

\section{Discussion, conclusion and recommendations}

\section{Discussion of Results}

COVID-19 has been accompanied by forced rapid changes in delivery of university education, the universities shuttered their doors and went virtual, and many brick-and-mortar universities were unprepared to pivot. The rapid changes in university education as result of COVID-19 has yielded mixed result. The lack of continuity in teaching and learning was at the heart of the crisis as most universities in Uganda are campus based (NCHE, 2020). With only seven universities out twenty included in the study having an effective risk management strategies. The universities indicated that they continued offering teaching materials but the access is being limited by lack of infrastructure and equipment by students and staff (BMAU, 2020).

The challenge of inadequate infrastructure and equipment to rollout ODeL cut across many countries in the world (Worldbank, 2020). This challenge of digital divide will widen the inequality gap across students living in rural and urban areas, as only 30.8 percent of the respondents indicated that the delivery modes being used by the universities does not benefit all the students. This is in line with BMAU report on the Education Sector interventions during the Corona Virus (COVID-19) Pandemic in Uganda. This requires medium term planning as appossed to short-term planning for example Estonia which is one of the leading in digital learning have been investing in developing a digital learning environment and e-study materials, accessible to a broader audience since 2015 (Worldbank, 2020). 


\section{International Journal of Social Science and Economic Research}

ISSN: $2455-8834$

Volume:06, Issue:04 "April 2021"

In addition, the uncertainty on when the universities will open affected the emergency planning. The NCHE will accredit institutions for ODeL programs for initial two years subject to renewal (NCHE, 2020). This has affected the medium and long term planning by universities in regard to investment in digitalization of their campuses (Worldbank, 2020). The lack of national elearning policy framework has made difficult for every university to fully rollout the ODeL programs. The issue of teaching practical lessons online, conducting community outreach and internships since most of the universities had not developed the virtual laboratories remains a challenge across universities during this period. There is need for development virtual laboratories to enhance online teaching of practical and practicum subjects.

The universities experienced a sharp decline in revenue collections, most of the private universities rely on tuition and functional fees from students. In addition, the closer of universities also affected other indirect revenues collected from hire of premises, rentals and services. The universities were not able to meet the costs of their critical requirements including paying of salaries for staff. This impacted on the capacity of the universities to continue offering teaching during COVID-19 lockdown. The private universities were worst hit but also Government universities, as most of their staffing levels are below 40 percent and reliance on part-timer to cover part of the teaching load.

The COVID-19 lockdown came at time when universities were soliciting applications for private entry scheme which affected the student admission and future enrollments. In addition, the university drop out will increase as result of economic recession which will leave most of the parents with no money to afford the university education (World Bank Group, 2020)

Besides the broad challenges it poses, the COVID-19 crisis might retrospectively be considered as an opportunity to strategically revamp systems and prepare for the challenges to come. The positive changes as a result of lockdown rotates from promotion of remote-working; development and implementation of online and blended programs; attitude change towards elearning training and increases innovation; improved technological competency of staff; increased lectures' collaboration and increased university partnerships mainly through sharing of materials. The universities were able to support the continuous learning as per government directive through mainly; using existing online distance learning platforms and resources, developing new online platform (virtual classrooms), posting materials on online website, and partnering with other education platforms such as zoom. The universities are mainly using Moodle, Google classroom ventures, Kolibri, Canvas, Zoom, webinars, Microsoft Teams, elearning materials donoted by Wolters-Kluwe, whatsapp and facebook.

\section{Conclusion}




\section{International Journal of Social Science and Economic Research}

ISSN: $2455-8834$

Volume:06, Issue:04 "April 2021"

Universities should consider not only making short-term adjustments in terms of accessibility, infrastructure, and equipment, but also drawing the right conclusions for the medium to long term. This applies not only to modalities for teaching and learning, where a stronger emphasis on blended learning and more and better opportunities for online learning will be a desirable result, but also a stronger emphasis on continuity of operations, student support, and welfare, including preparing for any possible future crises.

\section{Recommendations}

The study recommends that;

i. There is need to address infrastructure issues and lack of equipment for the university, staff and students. The Government should carry out a needs assessment study on the infrastructure and equipment needs of the universities both public and private and come up with the proper investment plan for providing them. This will help to reduce on duplications and promote economies of scale. In addition, it will also reduce the inequality gap resulting from the digital divide.

ii. The universities should consider sharing of educational materials and resources among themselves and other institutions even including sharing staff and e-libraries. In addition, universities should also utilize open-access resources provided by different countries. The sharing of staff will help the universities to reduce on the burden of understaffing.

iii. There is need for national digital policy learning framework. The framework will guide on the future operations and investments in the digital learning by all stakeholders. The guidelines for adoption of an emergency Open, Distance and e-learning (ODeL) System by the Higher Education Institutions during the covid-19 lockdown provided by NCHE focuses on short-term than medium and long term.

iv. Government should support the private universities to stay afloat. Government should exempt private universities and other institutions of higher learning from specific taxes and where necessary support the transition process including partly contributing to salaries for their staff as number of them are private not-for-profit. Universities stand a risk of opening campuses without staff since most of them are shifting to other economic activities for survival.

v. The universities should develop virtual laboratories to support the online teaching of practical and practicum subjects for today and future virtual learning and review the programs and ensure that they are accredited by NCHE as online programs as it requirement by law.

vi. The universities should train both students and staff on the use of digital delivery models before the implementation by the institution. This will solve the challenge of inadequacy of teachers to transform their material to suit online delivery modes. 
International Journal of Social Science and Economic Research

ISSN: 2455-8834

Volume:06, Issue:04 "April 2021"

vii. The universities through the University Forum need to pattern with government and internet service providers to ensure that student access zero-rated internet bandwidth. This will help all universities to move in the same direction rather than each university pushing on its own.

\section{References}

African Union . (2020). Impact of the Coronavirus (COVID 19) on the African Economy.

BMAU. (2020). The Education Sector interventions during the Corona Virus (COVID-19) Pandemic: How can they be more inclusive? Kampala: BMAU.

BOU. (2020). Monetary Policy Statement for April 2020. Kampala: Bank of Uganda.

Deloitte. (2020). COVID-19: Managing cash flow during a period of crisis. Deloitte.

Friedman, M. (2002). Capitalism and Freedom: Fortieth Anniversary Edition. Chicago : Chicago Press.

Jonathan Bundy, M. D. (2017). Crises and Crisis Management: Integration,Interpretation, and Research Development. Journal of Management, 1661-1692.

Matthias Wenzel, S. S. (2020). Strategic responses to crisis. SMS-WILEY, VIRTUAL SPECIAL ISSUE.

MoES. (2020, May 28). Minister of Education and Sports. Retrieved from Minister of Education and Sports: http://www.education.go.ug/

NCHE . (2020). Guidance to Universities and Tertiary Institutions in Uganda During the COVID-19 Lockdown. Kampala: NCHE .

NCHE. (2020). Guidelines for Adoption of an Emergency Open, Distance and E-Learning (ODeL) System by the Higher Education Institutions During the Covid-19 Lockdown. Kampala: NCHE.

New Vision. (2019, June 06). Universities: Student drop-out rates alarming. New Vision, pp. https:/www.newvision.co.ug/new_vision/news/1502587/universities-student-drop-ratesalarming.

Newvision . (2020, July 11). COVID-19: Private Varsities Ask for Help, p. 3.

NITAU. (2018). National Information Technology Survey 2017/18 Report. Kampala: CIPESA. 
International Journal of Social Science and Economic Research

ISSN: 2455-8834

Volume:06, Issue:04 "April 2021"

OECD. (2020). A $f$ ramework to guide an education response to the COVID-19 Pandemic of 2020. OECD.

QS. (2020). Developing Risk Management Strategies During a Crisis: How to Look Beyond. London: www.qs.com/consulting/.

QS. (2020). THE IMPACT OF THE CORONAVIRUS ON GLOBAL HIGHER EDUCATION. London, NW3 2DG: QS.

UNESCO. (2020). COVID-19 and higher education: Today and tomorrow. Paris: IESALC: UNESCO.

World Bank Group. (2020). The COVID-19 Pandemic: Schocks to Education and Policy Responses .

World Bank Group: Education. (2020). The COVID-19 Crisis Response:Supporting tertiary education for continuity, adaptation, and innovation. World Bank Group.

Worldbank. (2020). Tertiary Education and COVID-19: Impact and Mitigation Strategies in Europe and Central Asia. worldbank.

Worldometer. (2020). COVID-19 CORONAVIRUS PANDEMIC. 
International Journal of Social Science and Economic Research

ISSN: 2455-8834

Volume:06, Issue:04 "April 2021"

Annex 1: List of Universities that responded to the Questionnaire

\begin{tabular}{|c|c|c|}
\hline University Name & $\begin{array}{l}\text { Number } \\
\text { Respondents }\end{array}$ & $\begin{array}{l}\text { Ownership of the } \\
\text { University }\end{array}$ \\
\hline African Rural University & 1 & Private \\
\hline Bishop Stuart University & 1 & Private \\
\hline Clarke International University & 1 & Private \\
\hline Mountains of the Moon University & 1 & Private \\
\hline Ndejje University & 1 & Private \\
\hline Nexus International University & 1 & Private \\
\hline Nkumba University & 1 & Private \\
\hline St. Lawrence University & 1 & Private \\
\hline $\begin{array}{l}\text { Uganda } \\
\text { Campus }\end{array}$ Martyrs $\quad$ University-Kabale & 1 & Private \\
\hline Victoria University & 1 & Private \\
\hline YMCA Comprehensive Institute & 1 & Private \\
\hline Busitema University & 5 & Public \\
\hline Gulu University & 1 & Public \\
\hline Kabale University & 1 & Public \\
\hline Kyambongo University & 1 & Public \\
\hline Makerere University Business School & 3 & Public \\
\hline $\begin{array}{l}\text { Mbarara University of Science and } \\
\text { Technology }\end{array}$ & 1 & Public \\
\hline Muni University & 2 & Public \\
\hline Soroti University & 1 & Public \\
\hline Uganda Management Institute & 1 & Public \\
\hline Mildmay Institute of Health Sciences & 1 & Public \\
\hline
\end{tabular}

